\title{
ANALYSIS OF THE MORPHO-ANATOMICAL TRAITS OF FOUR MAJOR GARLIC (ALLIUM SATIVUM L.) CULTIVARS IN THE PHILIPPINES
}

\author{
RAGAS, R. E. G. ${ }^{*}-$ PADRON, F. K. J. R. ${ }^{2}-$ RUEDAS, M. Y. A. D. ${ }^{3}$ \\ ${ }^{I}$ Department of Biology and Environmental Science, College of Science, University of the \\ Philippines Cebu, Gorordo Avenue, Lahug, Cebu City, 6000 Cebu, Philippines \\ ${ }^{2}$ Philippine Rice Research Institute, Central Experiment Station, Maligaya, Science City of \\ Muñoz, 3119 Nueva Ecija, Philippines \\ ${ }^{3}$ Ocidental Mindoro State College, Quirino Street, San Jose, 5100 Occidental Mindoro, \\ Philippines \\ *Corresponding author \\ e-mail: rgragas@up.edu.ph; phone: +63-32-232-8187/ext.310 \\ (Received $24^{\text {th }}$ Sep 2018; accepted $2^{\text {nd }}$ Jan 2019)
}

\begin{abstract}
Cultivating garlic after the rice season has been increasingly attractive for rice farmers in the Philippines especially in areas where rice production is constrained by water scarcity. In Mindoro, Philippines, garlic cultivars planted include 'Mindoro White' (MW), 'Lubang' (LB), 'Batanes White' (BW), and 'Ilocos White' (IW). This study provides an in-depth analysis of major local garlic cultivars for classification and for selection of those with improved adaptation and marketability. For classification, we focused on phenotypic stable traits. Among these traits analyzed, clove weight $(\mathrm{p}<0.001)$ and number of bulb leaf sheaths $(\mathrm{p}<0.05)$ were significantly different. While there were small differences in their clove number and bulb color, bulb circumference $(\mathrm{p}<0.001)$ and weight $(\mathrm{p}<0.01)$ were highly significant. BW has the largest bulb circumference $(126.50 \pm 1.88 \mathrm{~mm})$ and weight $(22.38 \pm 0.94 \mathrm{~g})$ while $\mathrm{MW}$ has the smallest $(103.30 \pm 1.57 \mathrm{~mm})$ and is lightest $(13.78 \pm 0.50 \mathrm{~g})$. Bivariate analysis revealed that the highest bulb circumference and weight values of MW population correspond to the lowest values of BW population suggesting that these cultivars are two distinct populations. This was further supported by classical clustering analysis that distinguished them by bulb circumference $(87.12 \%)$, clove number $(76.01 \%)$ and number of clove vascular structures $(78.27 \%)$. Across cultivars, measurements of the epidermal and parenchymal cells significantly differed. Qualitative analysis of the bulb characteristics showed that BW exhibits a regular, multi-fan bulb structure with three layers of large cloves implying market attractiveness while IW's distinctly tight clove's skin indicates long storage potential.
\end{abstract}

Keywords: allium, bulb morphology, clove anatomy, cluster analysis, post-rice cultivation

\section{Introduction}

Garlic (Allium sativum L.) is a monocotyledonous herb that produces a bulb, an aggregate of sheath-covered cloves serving as the main economic organ (Stavelikova, 2008). It is the second most widely cultivated Allium distributed from boreal areas to tropic regions (Mhazo et al., 2014). Central Asia is recognized as the Allium's main center of origin which is supported by the discoveries of several primitive garlic types in the northwestern side Tien-Shan Mountains (Kotlinska et al., 1991; Etoh and Simon, 2002; Kamenetsky, 2007) and genetic fingerprinting (Volk et al., 2004; Kamenetsky et al., 2007; Zhao et al., 2011; Jo et al., 2012). It is also the home to the richest genetic diversity of garlic (Kamenetsky et al., 2007). 
In the Philippines, regions with Type I climate, characterized by a dry season during November to April, are main producers of garlic. Occidental Mindoro remains the second largest garlic producer, which shares $17 \%$ of the country's garlic national production (BAS, 2009). Farmers call it 'white gold' because it is a profitable crop planted in the fallow period after rice. Garlic cultivars usually grown in Mindoro include 'Lubang', 'Mindoro White, 'Batanes White' and 'Ilocos White'.

Morphological and anatomical studies are valuable in the Allium genus, since they provide suitable data for diagnosis of different taxa (Stearn, 1980; Fritsch and Friesen, 2002). Morphological traits of garlic are used in evaluating the diversity of garlic collection and classification based on phenotypic characters (Keller, 2002; Volk et al., 2004; Panthee, et al., 2006; Kamenetsky et al., 2007; Volk and Stern, 2009). However, since garlic is highly adaptive to its growth environment (Volk et al., 2004) and to different agroclimatic regions (Mario et al., 2008; Hirata et al., 2016), it is important to evaluate traits that were either influenced or not by growth environment for a reliable classification of cultivars. Moreover, Volk and Stern (2009) reported that clove arrangement, number of cloves, clove weight, clove skin color, and clove skin tightness were stable for each cultivar regardless of production location and conditions whereas those that vary with growth location include bulb traits.

The International Plant Genetic Resources Institute (IPGRI) Descriptor for Allium (2001) is the most common scheme used in evaluating and characterizing traits of garlic accessions. In addition, according to Miryeganeh and Movafeghi (2009), the anatomy of scapes and vegetative organs of Allium have been used for taxonomical purposes in different hierarchical levels. Most important anatomical studies on Allium were focused on the structure of the bulb scales (Fritsch, 1988), leaf (De Mason, 1990; Mathew, 1996), and scape (Miryeganeh and Movafeghi, 2009).

Given that garlic (A. sativum) is the only Allium that produces cloves, anatomy of clove and its potential use in the classification and delimitation of species of $A$. sativum is important. Hence, this work provides the clove anatomical findings on local garlic cultivars grown in the Philippines and represents some distinctions among cross-sections of cloves. Moreover, this study evaluated stable traits of four major garlic cultivars commonly grown in the Philippines to provide information in classification, market recognition, and identification of production-quality garlic.

\section{Materials and methods}

\section{Bulb and clove characteristics}

Four major local garlic cultivars were obtained from a garlic grower cooperative in Occidental Mindoro, Philippines (12 $2^{\circ} 21^{\prime} 19.2456^{\prime \prime} \mathrm{N}$ and $121^{\circ} 3$ ' 37.8324" E) which include 'Mindoro White (MW)', 'Lubang (LB)', 'Batanes White (BW)' and 'Ilocos White (IW)'. These garlic cultivars are the most common garlic planted for commercial production in major garlic provinces in the country. MW accessions are from Mindoro province while LB accessions are originally from the Lubang Island located in the northwest of the northern end of Mindoro (Fig. 1). The accessions IW and $\mathrm{BW}$ are from the northern provinces of the Philippines specifically in the provinces of Ilocos Norte and Batanes, respectively. 


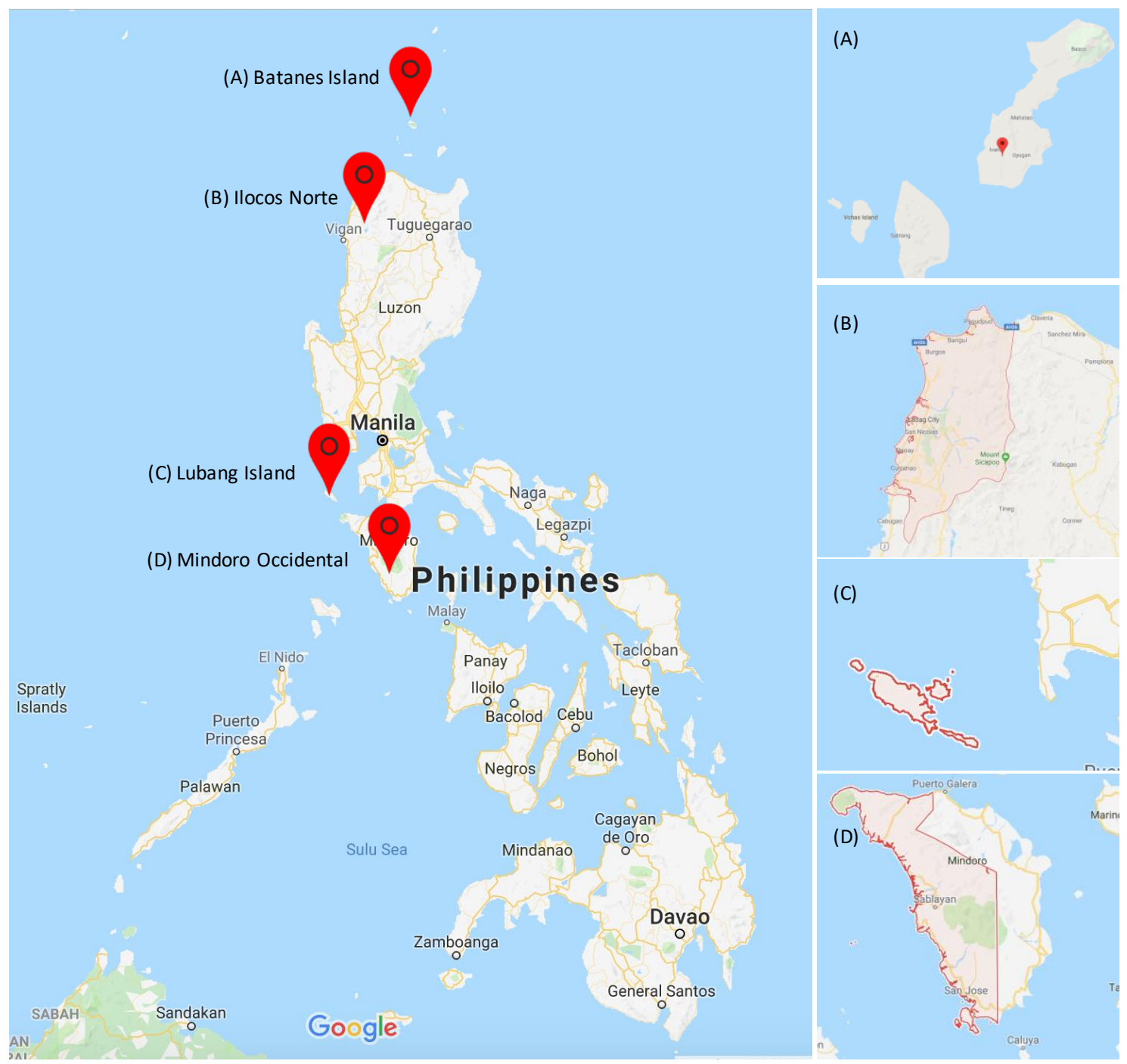

Figure 1. Location map of the origins of the garlic accessions in the Philippines. ' $B W$ ' in Batanes Island (A), 'IW' in Ilocos Norte (B), 'Lubang' in Lubang Island (C), and MW in Mindoro Occidental (D). (Google Map, 2018)

For each cultivar, nine bulbs (further categorized into large, medium, and small-sized bulbs, each having three representatives) were randomly selected to which phenotypic traits of the bulb and its cloves were analyzed based on IPGRI Descriptor for Allium (2001) (Fig. 2). Phenotypic data of the bulb collected from each cultivar include: sheath color and number, bulb shape, structure type, bulb circumference $(\mathrm{mm})$ and weight $(\mathrm{g})$. For the clove data, analysis on scale color and tightness, clove arrangement within a bulb, number of cloves per bulb, and weight (g) were made. In particular, the sheath and scale color as these are highly subjective, a color chart was used to distinguish intensity of color as indicated in the IPGRI (2001).

\section{Microscopy analysis}

The cross-sections of clove samples from each garlic cultivar were prepared and fixed in $70 \%$ ethanol for $48 \mathrm{~h}$. Following the methods of Gerlach (1977) as cited by Silva et al. (2015), they were then stained with safranin and fast green to distinguish the 
plant cell structures (Fig. 3). Thereafter, the sections were dehydrated through a graded ethanol series and then mounted on glass slide with a cover slip for observation. Each clove section was then examined under a light microscope (Axio Lab.A1, ZEISS, Germany) and dissecting microscope (Olympus, SZ61, Japan) linked to a digital camera. From the resulting images, sizes of the epidermal and parenchyma cells, size and number of rows of the vascular structures, and number of vascular structure per row were analyzed with Image J software (National Institutes of Health, USA).

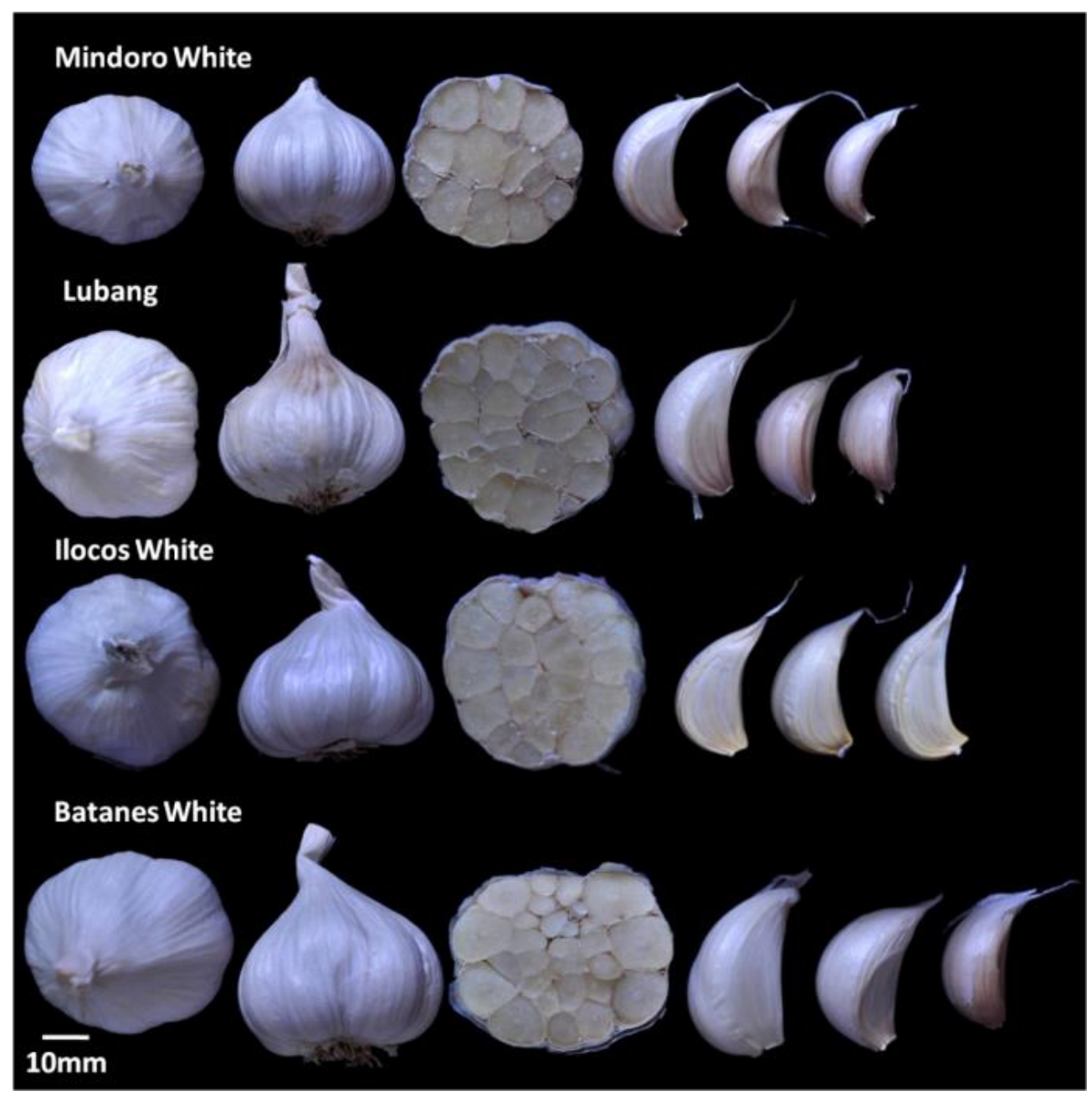

Figure 2. Bulb and clove characteristics of four major local garlic cultivars in the Philippines showing arrangement of cloves and coloration of bulb sheath and clove skin

\section{Statistical analysis}

Analysis of variance on quantitative data was performed using $\mathrm{R}$ Commander, a package available in $\mathrm{R}$ version 3.5.0. Qualitative data was summarized based on careful examinations of bulbs and cloves of each cultivar. Principal component analysis (PCA) was used to detect the characters that are most relevant to distinguish among the cultivars. Clusters of cultivars were formed on the basis of these factors using Classical Clustering Analysis (CCA). The graph representing classification is a dendrogram of similitude with standardized distances representing the closest cultivars in homogeneous groups. 


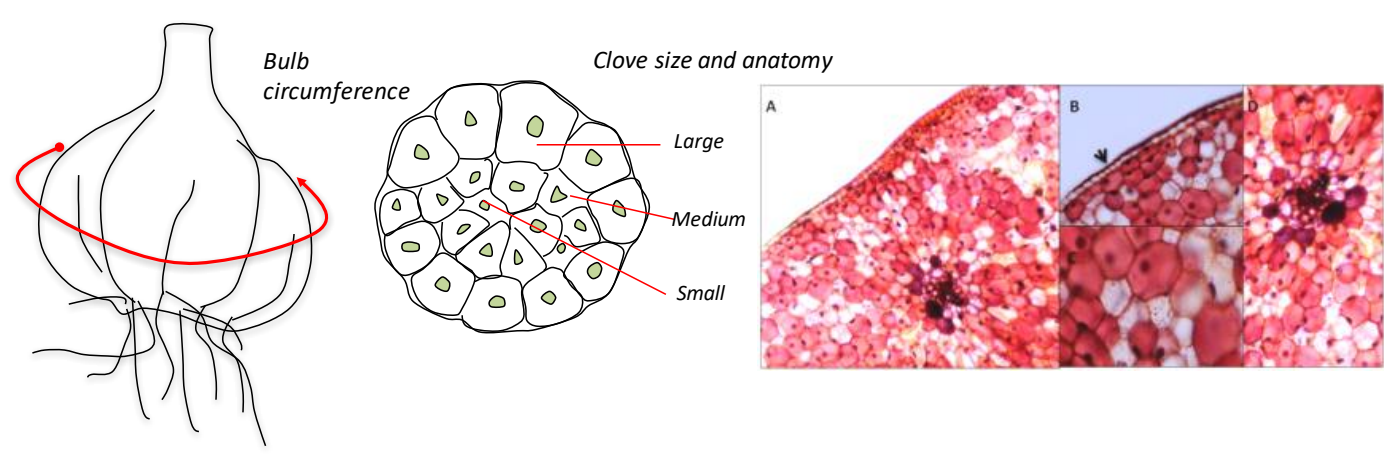

Figure 3. Diagrammatic presentation of parameters measured from bulb and clove characteristics as well as anatomical analysis of garlic cloves using safranin and fast green dyes under light microscope (A) Clove section under LPO (10x), (B) Epidermal cells (arrow head), (C) Normal clove cells with nuclei, (D) Vascular tissue under HPO (40x)

\section{Results}

\section{Bulb characteristics}

Color and pattern of bulb sheath were similar among cultivars except for LB which had darker sheath and more prominent brown stripes. MW, BW and IW all had white sheath with brown stripes. Similarities on the bulb shape and its structure type were also observed among cultivars. The bulb shape of MW and LB was circular with a prominent basal plate, BW and IW, were broadly ovate with an even (same level as the cloves) basal plate (Table 1). The MW and IW had similar bulb structure type which is regular two-fan groups while LB and BW had regular multi-fan groups. Regular twofan groups have large outer cloves and small inner cloves while regular multi-fan groups have large outer cloves, medium inner cloves and small innermost cloves.

Table 1. Bulb and clove morphological characteristics of four garlic cultivars grown in the Philippines

\begin{tabular}{c|c|c|c|c|c|c}
\hline \multirow{2}{*}{ Cultivar } & \multicolumn{4}{|c|}{ Bulb } & \multicolumn{2}{c}{ Clove } \\
\cline { 2 - 7 } & Sheath color & Shape & Structure type & Scale color & $\begin{array}{c}\text { Scale } \\
\text { tightness }\end{array}$ & Arrangement \\
\hline $\begin{array}{c}\text { Mindoro } \\
\text { White }\end{array}$ & $\begin{array}{c}\text { White/light } \\
\text { brown stripe }\end{array}$ & $\begin{array}{c}\text { Circular, basal } \\
\text { plate prominent }\end{array}$ & $\begin{array}{c}\text { Regular two-fan } \\
\text { groups }\end{array}$ & $\begin{array}{c}\text { Tan lower and } \\
\text { white/pale upper }\end{array}$ & Loose & 2 layers \\
\hline Lubang & $\begin{array}{c}\text { White- } \\
\text { tan/moderate } \\
\text { brown stripe }\end{array}$ & $\begin{array}{c}\text { Circular, basal } \\
\text { plate prominent }\end{array}$ & $\begin{array}{c}\text { Regular multi-fan } \\
\text { groups }\end{array}$ & $\begin{array}{c}\text { Brown lower and } \\
\text { white/pale upper }\end{array}$ & Moderate & 3 layers \\
\hline $\begin{array}{c}\text { Batanes } \\
\text { White }\end{array}$ & $\begin{array}{c}\text { White/light } \\
\text { brown stripe }\end{array}$ & $\begin{array}{c}\text { Broadly ovate, } \\
\text { basal plate even }\end{array}$ & $\begin{array}{c}\text { Regular multi-fan } \\
\text { groups }\end{array}$ & $\begin{array}{c}\text { Light brown/tan } \\
\text { lower and white } \\
\text { upper }\end{array}$ & Moderate & 3 layers \\
\hline $\begin{array}{c}\text { Ilocos } \\
\text { White }\end{array}$ & $\begin{array}{c}\text { White/light } \\
\text { brown stripe }\end{array}$ & $\begin{array}{c}\text { Broadly ovate, } \\
\text { basal plate even }\end{array}$ & $\begin{array}{c}\text { Regular two-fan } \\
\text { groups }\end{array}$ & $\begin{array}{c}\text { Yellowish lower and } \\
\text { white/pale upper }\end{array}$ & Snug & $2-3$ layers \\
\hline
\end{tabular}

Significant differences in bulb weight and circumference were observed among four garlic cultivars (Fig. 4). Bulb circumference and weight of 'LB' (122.46 $\pm 2.20 \mathrm{~mm}$ and $18.8 \pm 1.16 \mathrm{~g})$ is comparable with IW $(119.32 \pm 1.26 \mathrm{~mm}$ and $19.77 \pm 0.76 \mathrm{~g})$. Among the cultivars, BW produced the biggest and heaviest bulb while MW had the smallest 
and consequently the lightest. Bulb sheath number, ranges from five to seven with MW having the most number of sheath.
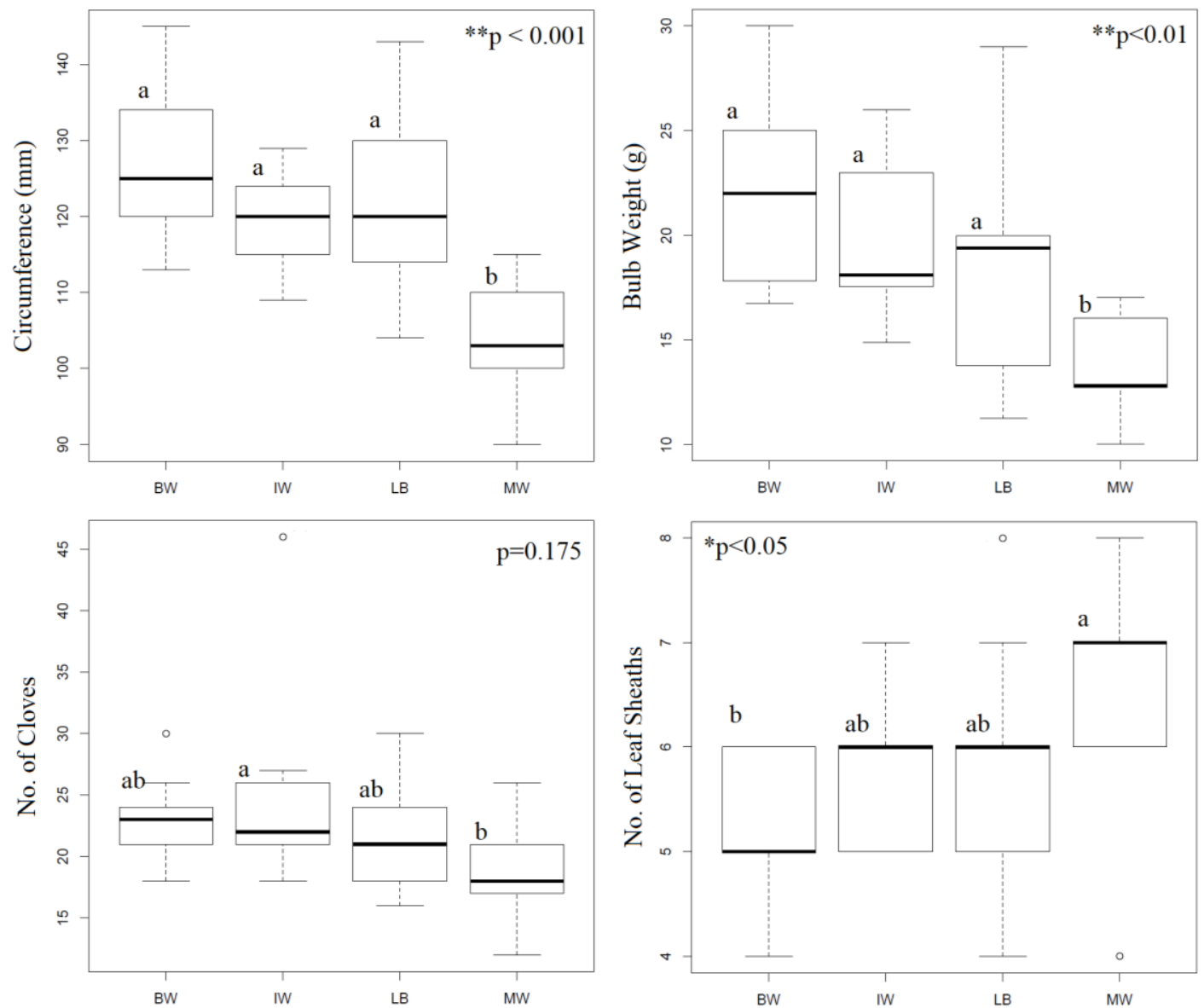

Figure 4. Bulb characteristics of four garlic cultivars in the Philippines. $B W=$ Batanes White, $I W=$ Ilocos White, $L B=$ Lubang, $M W=$ Mindoro White

Bivariate analysis of bulb circumference and weight through $95 \%$ confidence ellipse was used to estimate the population of each cultivar (Fig. 5). The results revealed that the common weight and circumference ranges of the four cultivars fall in the 15-18 $\mathrm{g}$ and $110-118 \mathrm{~mm}$, respectively. While there exist two distinct cultivars, namely BW and MW, overlapping of bulb characteristics was still observed. The most notable overlap was between the smallest and lightest predicted populations of BW and the largest and heaviest populations of MW. Moreover, the population of IW cultivars was within the boundaries of the BW population, and that the largest bulb characteristic values of IW only reached the median values of BW. The LB, on the other hand, showed a wide range of bulb characteristics. While its bulb circumference and weight were comparably higher than MW and IW, it did not completely share with the BW population. Additionally, LB circumference and weight showed weaker correlation compared with the correlations observed in other cultivars. For instance, the bulb circumference of LB that were on the same circumference range as the other three cultivars weighed on the lower weight range, in fact, LB's largest bulbs were not necessarily heavier than their smaller counterparts from other cultivars. 


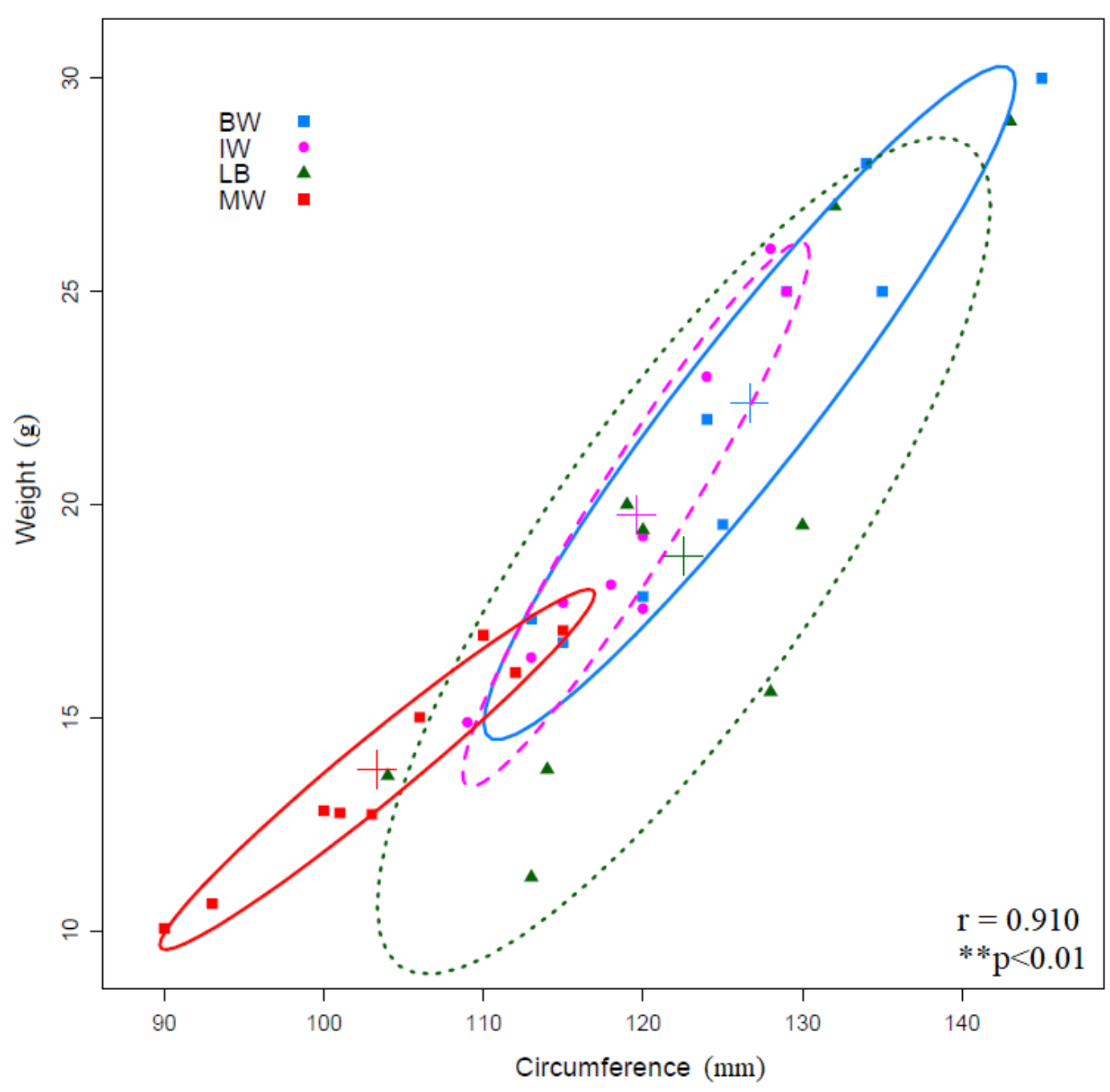

Figure 5. Scatter plot of bulb weight and circumference of four garlic cultivars in the Philippines using 95\% confidence ellipse visualization ( $R$ Studio). $B W=$ Batanes White, $I W=$ Ilocos White, $L B=$ Lubang, $M W=$ Mindoro White

\section{Clove characteristics}

Cultivars were classified according to clove scale color and tightness, number of cloves per bulb, clove arrangement and clove weight (Table 1 and Fig. 4). Two hues of clove skin color were observed among cultivars. Different clove skin colors were also observed varying from tan to yellowish upper part to pale-white lower part. High variability was observed at the lower part of the clove skin and not as much in the upper part. White-pale upper part was observed in all cultivars except for BW which only had a white upper part. For the color of lower part, MW, LB, BW, and IW had tan, brown, light brown-tan, and yellowish, respectively. Clove skin tightness varied from snug to loose (Table 1). Clove arrangement within the bulb varied from two layers as observed in MW, two to three layers in IW, and three layers in BW and LB.

A significant difference in clove weight among garlic cultivars was observed (Fig. 6). The clove weight of MW is significantly different from other cultivars except for LB. Clove number per bulb among cultivars were not significantly different from 
each other (Fig. 4). The IW produced the most numerous cloves per bulb while BW had the highest clove weight. The MW produced the fewest cloves and the lightest clove weight (Figs. 4 and 6). It was also observed that the larger the cloves produced, the heavier the bulb.

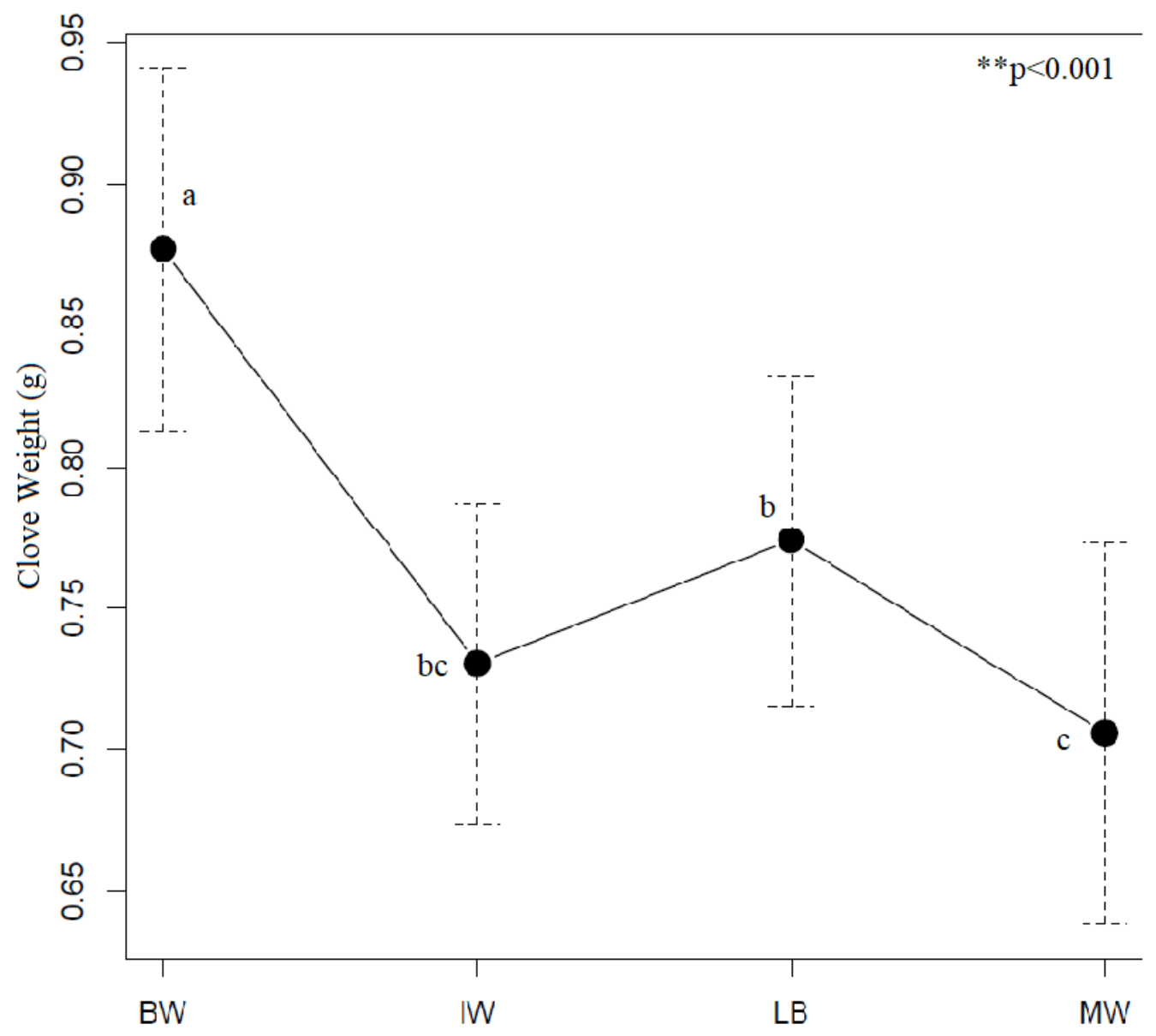

Figure 6. Clove weight of four garlic cultivars in the Philippines. $B W=$ Batanes White, $I W=$ Ilocos White, $L B=$ Lubang, $M W=$ Mindoro White

The dendrogram gave the clustering pattern for the garlic cultivars shown in Figure 7. There were two main clusters; the BW cultivar cluster and the other cultivars. The MW and LB cultivars were classified into the same group, but the IW cultivar was separated into a minor group. The distances between the cultivars ranged from 0.99 to 1.00 , suggesting that genetic diversity between the garlic cultivars was moderately high.

\section{Anatomical characterization}

Differences in shape of clove's cross-sections were observed. The shape of the clove cross-sections was elliptic-oblong in MW and LB, circular in BW and cuboidal in IW. Across cultivars, epidermis was single layered with a thin cuticle outer covering. Epidermal cells were more or less isodiametric-cuboidal. Minimum width of epidermal cells across cultivars was $0.020 \mathrm{~mm}$. BW had the biggest (width: $0.040 \pm 0.002 \mathrm{~mm}$ ) and thickest (length: $0.035 \pm 0.002 \mathrm{~mm}$ ) layer of epidermal cells among the cultivars (Table 2). Thinnest epidermal cell layer was observed in MW. 


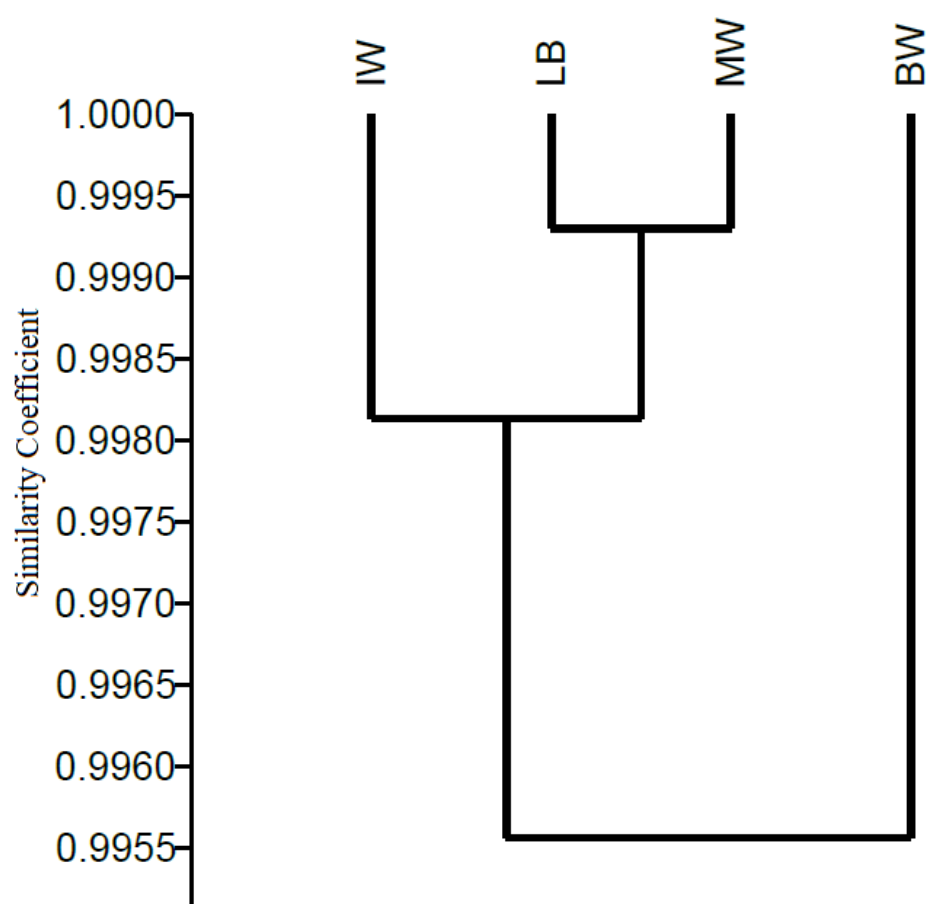

Figure 7. Similarity dendrogram generated by classical cluster analysis (CCA) using PAST 3.15 software showing two major clusters on the basis of morphology and anatomical characters of four garlic (Allium sativum L.) accessions in the Philippines. BW $=$ Batanes

White, $I W=$ Ilocos White, $L B=$ Lubang, $M W=$ Mindoro White

Table 2. Anatomical characteristics of the cloves of four garlic cultivars grown in the Philippines

\begin{tabular}{c|c|c|c|c|c|c}
\hline \multirow{2}{*}{ Cultivar } & \multicolumn{2}{|c|}{ Epidermal cell } & \multicolumn{2}{c|}{ Parenchymal cell } & \multicolumn{2}{c}{ Vascular structure } \\
\cline { 2 - 7 } & Width (mm) & Length (mm) & Width (mm) & Length (mm) & Width (mm) & Length (mm) \\
\hline MW & $0.034 \pm 0.002$ & $0.019 \pm 0.001$ & $0.111 \pm 0.004$ & $0.130 \pm 0.006$ & $0.167 \pm 0.008$ & $0.184 \pm 0.019$ \\
LB & $0.030 \pm 0.001$ & $0.028 \pm 0.001$ & $0.109 \pm 0.005$ & $0.113 \pm 0.006$ & $0.152 \pm 0.010$ & $0.178 \pm 0.014$ \\
BW & $0.040 \pm 0.002$ & $0.035 \pm 0.002$ & $0.111 \pm 0.005$ & $0.150 \pm 0.006$ & $0.183 \pm 0.130$ & $0.213 \pm 0.014$ \\
IW & $0.036 \pm 0.002$ & $0.029 \pm 0.002$ & $0.119 \pm 0.005$ & $0.130 \pm 0.007$ & $0.149 \pm 0.005$ & $0.200 \pm 0.014$ \\
p-value & 0.002 & 0.000 & 0.426 & 0.006 & 0.049 & 0.321 \\
LSD (5\%) & 0.004 & 0.004 & 0.013 & 0.017 & 0.020 & 0.029 \\
\hline
\end{tabular}

Values are means \pm standard errors

$\mathrm{BW}=$ Batanes White, $\mathrm{IW}=$ Ilocos White, $\mathrm{LB}=$ Lubang, $\mathrm{MW}=$ Mindoro White

Parenchymal cells vary from hexagonal to ovoidal. LB had the smallest parenchyma cells while IW (in terms of width) and BW (in terms of length) have the largest (Table 2). Cell staining revealed that parenchyma cells contained compounds but were mostly starch granules. Most of the parenchyma cells of LB contained starch and carbohydrates while only few carbohydrates containing parenchyma cells were observed in MW.

The vascular structures were arranged in a ring like pattern in cortex which is commonly observed in monocots. They were collateral in all cultivars. Furthermore, vascular structures were surrounded with vascular sheaths consisting of some layers of 
small parenchyma cells. BW had the largest vascular structure in terms of length and width while LB had the smallest (Table 2). One to three layers of vascular structures were observed across cultivars. The BW had the most number of vascular structures (3 layers) per clove while MW (1-2 layers) had the fewest. Width and length of cells of different tissues were not congruent. A cultivar with the highest cell width does not imply that it also had the utmost length.

\section{Multivariate analyses}

Classical clustering analysis was used to detect similarities among cultivars using quantitative variables that were statistically significant and all of the qualitative variables. The analysis showed two major groups having BW the least similar $(99.56 \%)$ cultivar compared with other cultivars, while IW shared $99.80 \%$ similarity with a second group, LB and MW. The LB and MW shared the highest similarity $(99.93 \%)$ among all cultivars (Fig. 7).

Cross-validating the results with the PCA, the first three PCA axes described $97.71 \%$ of the total variance, thus indicating that these three axes represent the majority of the variation for the morphological and anatomical characteristics. The first axe accounts for $87.12 \%$ variability, which is correlated to the bulb circumference and bulb weight. The second axe represents $78.27 \%$ of the variation, which represents the characteristics of the vascular structure number within the clove and the third axe separates the cultivars on the basis of their clove number.

\section{Discussion}

Variation in both qualitative and quantitative characters was observed in this study. We focused our analysis on bulb and clove traits primarily because they are the economic organs of garlic used in culinary, medicine, and propagation. Bulb weight, in particular, is the parameter which has the most direct impact on garlic yield as it represents the most significant production characteristics and its market value (Moravčević et al., 2017). According to Panthee et al. (2006), variation in qualitative characters are useful for varietal descriptor and variety identification, in contrast to quantitative characters that have direct application in variety improvement programs owing to its agronomic interest.

Bulb circumference and weight of the four cultivars in this study were significantly different with BW being the largest and heaviest bulb, followed by IW, LB and then, MW being the smallest and lightest. The largeness and heaviness of BW could be accounted to the number of cloves and clove weight. The present finding is in accordance with the results of Islam et al. (2007) and Yeshiwas et al. (2018) who reported significant variation for bulb weight due to genotypic difference. Additionally, in India, Rakesh Sharma et al. (2018) found that bulb diameter and weight contributed maximum towards the total variability in their evaluated germplasm. The slight change in order between IW and LB in terms of clove weight could be due to carbohydrates stored in their clove's cells. The cells of LB cloves were anatomically small but had more carbohydrates containing parenchyma cells as revealed after cell staining. Plant cells contain large amount of carbohydrates such as starch, glycogen and cellulose, which are important for energy, structure, storage and increasing biomass (Guertin and Sabatini, 2005). In garlic, carbohydrates play an important role from dormancy and sprouting (Mashayekhi et al., 2016). 
Hirata et al. (2016) evaluated garlic diversity based on morphological, physiological and isozyme variation of collected germplasm from Asia including Southeast Asia and reported that all accessions from tropical regions have comparable bulb yield in terms of weight and circumference as well as number and weight of cloves. Menezes-Sobrinho et al. (1999) identified bulb weight and bulb skin color among many characters to have a combination of qualitative and quantitative characters in principal components which are similar to the present study. In this study, cultivars differed in qualitative traits including bulb shape and structure type, and bulb sheath number and color. These traits are considered valuable for market recognition (Volk et al., 2004) because consumers are attracted to colorful, bigger, flavorful and unique types of garlic for different culinary purposes. While BW is easily distinguished as the biggest garlic, LB could be the choice for a colorful garlic due to its unique bulb sheath color. The MW, on the other hand, would be a preferred cultivar for flavor and aroma, which are ascribed to its small bulb size similar to the findings of Medina and Garcia (2007).

With regard to bulb structure type, both LB and BW have a regular multi-fan groups with cloves arranged in three layers within a bulb. This type of garlic is a valuable specimen for propagation as overall bulb yield and quality are influenced, not only by growth location and farmer's management practice (Volk and Stern, 2009), but also by the size and quality of the planting stock (Conci et al., 2003 Melo et al., 2006). Initial planting stock that is of sufficient size and quality yields higher harvests because it can produce bigger bulb circumference and considered as more valuable commercial assets (Castellanos et al., 2004). Each clove can develop a new plant and often, large-sized cloves are utilized as seedlings. Heredia et al. (1997) and Gwandu and Isa (2016) reported that bulb selection based on the number of cloves are partially due to findings that a bulb with few cloves produces large individual seeds, which in turn contributes to a greater bulb yield, but does not imply the use of a greater amount of seed. However, in this study, cultivars that have bulb with many cloves produced larger individual seeds as observed in BW.

Obtaining only three distinct clusters from sampled cultivars indicates that there must be a frequent material flow from one place to another owing to the small geographical region of the Philippines. Garlic is a clonally propagated species, which may reduce variation hence little number of clusters. This observation is congruent to several studies on diversity analysis of garlic germplasm in other countries in which despite large geographical coverage and number of garlic accessions, only a few clusters were derived. For example, Panthee et al. (2006) examined 179 garlic germplasms in Nepal and found only three clusters. Menezes-Sobrinho et al. (1999) characterized 89 garlic germplasms of Brazil and found 13 clusters. Lallemand et al. (1997) evaluated 65 garlic accessions and found six clusters on the basis of morphological characters. Hence, three clusters from a relatively small geographical coverage in the Philippines are reasonable. However, it is noteworthy that local garlic cultivars evaluated in this study have much larger circumference than those reported by Hirata et al. (2016).

Garlic from warm, short-day lowland tropical regions produces poor bulbs as compared with garlic from temperate zones, which produces bigger bulbs, where days are longer and winters are cold (Brewster, 2008). Bulb formation is greatly influenced by photoperiod and temperature (Brewster, 1990). In an attempt to improve garlic bulb size in the tropics, Ragas et al. (2016) studied the effect of night break on phenotypic traits of locally produced and one imported cultivar planted in selected Philippine provinces. They observed that all garlic cultivars produced larger bulbs when exposed 
to night break treatment than those in natural sunlight. Interestingly, BW in this study had larger and heavier bulb produced than 'Taiwan', the imported accession reported by Ragas et al. (2016). Hence, locally-produced cultivar especially BW has the potential to outperform imported garlic available in the Philippine market.

The shape of the clove's cross- sections differed among the cultivars studied. However, the shape of the cross-section of cloves and bulbs of LB and MW were relatively similar probably because of the proximity in the geographical origins of these cultivars. The LB cultivars were originally from Lubang, an island, northwest of Mindoro province. However, Batanes, where BW originated, is a province of some distance from the other provinces (Ilocos and Mindoro), which may be the reason for the distinct differences between the BW and the other garlic cultivars studied. In all cultivars examined, the clove epidermis consisted of a single cell layer, which is congruent to the observations of Miryeganeh and Movafeghi (2009) in scape and Mashayekhi and Columbus (2014) in leaf blade structures of Allium species. Size of cells in epidermis, ground and vascular tissues differed from one cultivar to the other. Observations on plants suggest that growth and most morphology do not depend on the number of cells or their size within an organ (Walbot, 2012). This matches the result obtained in this study wherein a cultivar with smallest bulb circumference is not the cultivar with the smallest cell size or vice versa. Plant cells have their own adaptations to achieve near normal morphology despite fewer cells or small cell size (Haber and Foard, 1961). For instance, the LB had smaller cell size than MW even if the latter had smaller bulb circumference.

Anatomical characterization of several cross-sections of the clove revealed that cell size is invariable within a given cultivar; therefore, a useful criterion for grouping similar cultivars. On the other hand, the layers and number of vascular structures per layer are inconsistent among cultivars studied implying that it is an important anatomical character for taxonomic classification. These were confirmed in the clustering analysis which detected highest similarities between LB and MW cultivars, both originally from Mindoro province; and the BW consistently remained the least similar with the rest of the cultivars studied.

\section{Conclusion}

This study established the morpho-anatomical characterization of major Philippine garlic cultivars by analyzing stable phenotypic traits which are expected to facilitate efficient measure for revealing relationships and detecting morphologically similar garlic cultivars. The results point at one population (BW) that displayed significant bulb traits and suggest that this cultivar could be further improved to match desirable traits of an imported garlic available in the Philippine market. To represent a richer selection base, however, for the needs of culinary and pharmaceutical purposes, it is recommended that future work should consider larger number of germplasms and should be tested at multi-location sites for national variety trial test useful for dissemination to researchers, farmers, and consumers.

Acknowledgements. Authors would like to thank Korean Program for International Agriculture (KOPIA) for the research fund provided. MAGRO and First Christian Cooperative for providing the garlic cultivar samples. Assistance in garlic collection ably supported by Emmanuel G. Ruedas, Jennifer M. Manangkil, and Marcelino L. Marturillas are highly appreciated. 


\section{REFERENCES}

[1] Brewster, J. L. (1990): Physiology of Crop Growth and Bulbing. - In: Rabinowitch, H. D., Brewster, J. L. (eds.) Onions and Other Vegetable Alliums. CRC Press, Boca Raton, FL, pp. 53-88.

[2] Brewster, J. L. (2008): Onions and Other Vegetable Alliums, $2^{\text {nd }}$ ed. - CABI Publishing, Wallingford, Oxfordshire, UK.

[3] Bureau of Agricultural Statistics (2009): Department of Agriculture Philippines. https://psa.gov.ph/sites/default/files/commodity_factsheet2009.pdf (accessed 27 November 2017).

[4] Castellanos, J. Z., Vargas-Tapia, P., Ojodeagua, J. L., Hoyos, G. (2004): Garlic productivity and profitability as affected by seed clove size, planting density and planting method. - Horticultural Science 39(6): 1272-1277.

[5] Conci,V. C., Canavelli, A., Lunello, P., DiRienzo, J., Nome, S. F., Zumelzu, G., Italia, R. (2003): Yield losses associated with virus-infected garlic plants during five successive years. - Plant Disease 87: 1411-1415. http://dx.doi.org/10.1094/PDIS.2003.87.12.1411.

[6] De Mason, D. A. (1990): Morphology and Anatomy of Allium. - In: Rabinowitch, H. D., Brewster, J. L. (eds.) Onions and Allied Crops (Vol. 1). CRC Press, Boca Raton, FL, pp. 27-51.

[7] Etoh, T., Simon, P. W. (2002): Diversity, Fertility and Seed Production in Garlic. - In: Rabinowitch, H. D., Currah, L. (eds.) Allium Crop Science: Recent Advances. CAB International, Wallingford, Oxon, pp. 101-117.

[8] Fritsch, R. M. (1988): The root anatomy of the genus Allium L. (Alliaceae). - Beiträge zur Biologie der Pflanzen 67: 129-160.

[9] Fritsch, R. M., Friesen, N. (2002): Evolution, Domestication and Taxonomy. - In: Rabinowitch, H. D., Currah, L. (eds.) Allium Crop Science: Recent Advances. CABI Publishing, Wallingford, Oxfordshire, UK. pp 5-27.

[10] Gerlach, D. (1977): Botanische Mickrotechnik. - Thieme Verlag, Stuttgart.

[11] Google (2018): Google map of Mindoro, Philippines. https://goo.gl/maps/sz6CY9npRGp (accessed 9 November 2018).

[12] Guertin, D. Sabatini, D. (2005): Cell Size Control. - Encyclopedia of Life Sciences, John Wiley \& Sons, London, pp. 1-10. DOI: 10.1038/npg.els.0003359.

[13] Gwandu, H. A., Isa, Y. S. (2016): Effects of clove size and defoliation intensity on the growth and yield of garlic (Allium sativum L.) in Sokoto, Nigeria. - International Journal of Research in Engineering and Science 4(9): 37-41.

[14] Haber, A., Foard, D. (1961): Anatomical analysis of wheat growing without cell division. - American Journal of Botany 4: 438-446.

[15] Heredia, A., Heredia, E., Laborde, J. A. (1997): Number of cloves per bulb; selection criteria for garlic improvement. II Results with "Taiwan" type. - Acta Horticulturae. 433: 271-277. https://doi.org/10.17660/ActaHortic.1997.433.26.

[16] Hirata, S., Abdelrahman, M., Yamauchi, N., Shigyo, M. (2016): Diversity evaluation based on morphological, physiological and isozyme variation in genetic resources of garlic (Allium sativum L.) collected worldwide. - Genes and Genetic Systems 91: 161173. https://doi.org/10.1266/ggs.15-00004.

[17] IPGRI ECP/GR, AVRDC (2001): Descriptors for Allium (Allium spp.) - International Plant Genetic Resources Institute, Rome, European Cooperative Programme for Crop Genetic Resources Networks (ECP/GR). Taipei, Asian Vegetable Research and Development Center, pp. 1-42.

[18] Islam, M. J., Ak, M., Hossain, M., Khanam F, Majumder, U. K., Rahman, M. M., Rahman, M. S. (2007): Effect of mulching and fertilization on growth and yield of garlic at Dinajpur in Bangladesh. - Asian Journal of Plant Science 6(1): 98-101. 
[19] Jo, M. H., Ham, I. K., Moe, K. T., Kwon, S. W., Lu, F. H., Park, Y. J., Kim, W. S, Won, M. K., Kim, T. I. Lee, E. M. (2012): Classification of genetic variation in garlic (Allium sativum L.) using SSR markers. - Australian Journal of Crop Science 6: 625-631.

[20] Kamenetsky, R. (2007): Garlic: botany and horticulture. - Horticultural Reviews 33: 123172.

[21] Kamenetsky, R., Khassanov, F., Rabinowitch, H. D., Auger, J., Kik, C. (2007): Garlic and Aromatic. - Plant Science and Biotechnology 1(1): 1-5.

[22] Keller, E. R. J. (2002): Cryopreservation of Allium Sativum L. (Garlic). - SpringerVerlag, Berlin, pp. 37-47.

[23] Kotlinska, T., Havranek, P., Navratill, M., Gerasimova, L., Pimakhov, A., Neikov, S. (1991): Collecting onion, garlic and wild species of Allium in Central Asia, USSR. FAO/IBGR. - Plant Genetic Resources 83(84): 31-32.

[24] Lallemand, J., Messian, C. M., Briand, F., Etoh, E. (1997): Delimitation of varietal groups in garlic (Allium sativum L.) by morphological, physiological and biochemical characters. (In: Burba, J. L., Galmarini, C. R. (eds.) Proceedings on First International Symposium on Edible Alliaceae.) - Acta Horticulturae 433: 123-129.

[25] Mario, P. C., Viviana, B. V., Maria, I. G. A. (2008): Low genetic diversity among garlic Allium sativum L.) accessions detected using random amplified polymorphic DNA (RAPD). - Chilean Journal Agricultural Research 68(1): 3-12.

[26] Mashayekhi, K., Mohammadi Chiane, S., Mianabadi, M., Ghaderifar, F., Mousavizadeh, S. J. (2016): Change in carbohydrate and enzymes from harvest to sprouting in garlic. Food Science Nutrition 4: 370-376. DOI: 10.1002/fsn3.299.

[27] Mashayekhi, S., Columbus, J. T. (2014): Evolution of leaf blade anatomy in Allium (Amaryllidaceae) subgenus Amerallium with a focus on the North American species. American Journal of Botany 101(1): 63-85. https://doi.org/10.3732/ajb.1300053.

[28] Mathew, B. (1996): A review of Allium Sect. Allium. - Royal Botanic Gardens, Kew.

[29] Medina, J. D. Garcia, H. S. (2007): Garlic post-harvest operations. Food and Agricultural Organization.

http://www.fao.org/fileadmin/user_upload/inpho/docs/Post_Harvest_Compendium__Garlic.pdf (accessed 24 February 2018).

[30] Melo, P. D., Resende, R. O., Cordeiro, C. M. T., Buso, J. A., Torres, A. C., Dusi, A. N. (2006): Viral reinfection affecting bulb production in garlic after seven years of cultivation under field conditions. - European Journal of Plant Pathology 116: 95-101. https://doi.org/ 10.1007/s10658-006-9042-3.

[31] Menezes-Sobrinho, J. A., de Charchar, J. M., Aragao, F. A. S., Menezes-Sobrinho, J. A. (1999): Morphological characterization of garlic germplasm by multivariate analyses of principal components and canonic variables. - Horticultura Brasileira 17: 96-101.

[32] Mhazo, M. L., Ngwerume, F. C. Masarirambi, M. T. (2014): Garlic (Allium sativum) propagation alternatives using bulblets and cloves of different sizes in a semi-arid subtropical environment. - Annual Research and Review in Biology 4(1): 238-235.

[33] Miryeganeh, M., Movafeghi, A. (2009): Scape anatomy of Allium sect. (Alliaceae) in Iran. - Journal of Science (University of Tehran) 35(1): 1-5.

[34] Moravcevic, D., Varga, J., Pavlovic, N., Todorovic, V., Ugrinovic, M. (2017): Production and chemical characteristics of the populations of spring garlic (Allium sativum L.) from the Serbian genetic collection. - Emirates Journal of Food and Agriculture 29(3): 227236. https://doi.org/https://doi.org/10.9755/ejfa.2016-11-1680.

[35] Panthee, D. R., KC, R. B., Regmi, H. N., Subedi, P. P., Bhattarai, S., Dhakal, J. (2006): Diversity analysis of garlic (Allium sativum L.) germplasms available in Nepal based on morphological characters. - Genetic Resources and Crop Evolution 53(1): 205-212. https://doi.org/10.1007/s10722-004-6690-z.

[36] Ragas, R. E. G., Guittap, C. F. C., Bongat, F. B., Lee, J. T., Rasco, E. T. (2016): Initial studies on increasing garlic bulb size through night-break treatment in the Philippines. Acta Horticulturae 1134: 131-137. https://doi.org/10.17660/ActaHortic.2016.1134.18. 
[37] Rakesh Sharma, V., Malik, S., Kumar, M., Sirohi, A. (2018): Morphological classification of genetic diversity of Garlic (Allium sativum L.) germplasm for bulb and yield-related traits using principal component analysis. - International Journal of Current Microbiology and Applied Science 7(6): 2016-2022. https://doi.org/10.20546/ijcmas.2018.706.238.

[38] Silva, T. M., Vilhalva, D. A. A., Moraes, M. G., Figueiredo-Ribeiro, R. C. L. (2015): Anatomy and fructan distribution in vegetative organs of Dimerostemma vestitum (Asteraceae) from the campos rupestres. - Anais da Academia Brasileira de Ciencias 87(2): 797-812. https://doi.org/10.1590/0001-3765201520140214.

[39] Stavelikova, H. (2008): Morphological characteristics of garlic (Allium sativum L.) genetic resources collection information. - Horticultural Science (Prague) 35(3): 130-135. https://doi.org/ 0.17221/661-HORTSCI.

[40] Stearn, W. (1980): Allium L. - In: Tutin, T., Heywood, W., Burges, N., Moore, D., Valentine, D., Walters, S., Webb, D. (eds.) Flora Europaea, Vol. 5. Cambridge University Press, Cambridge, pp. 49-69.

[41] Volk, G. M., Stern, D. (2009): Phenotypic characteristics of ten garlic accessions grown at different North American locations. - Horticultural Science 44(5): 1238-1247.

[42] Volk, G. M., Henk, A. D., Richards, C. M. (2004): Genetic diversity among US garlic clones as detected using AFLP methods. - Journal of American Society for Horticultural Science 129: 559-569.

[43] Walbot, V. (2012): Thinking inside the wooden box- classic views of cell size control in plants. - BMC Biology 10: 101.

[44] Yeshiwas, Y., Negash, B., Walle, T., Gelaye, Y., Melke, A., Yissa, K. (2018): Collection and characterization of garlic (Allium sativum L.) germplasm for growth and bulb yield at Debre Markos, Ethiopia. - Journal of Horticulture and Forestry 10(3): 17-26. https://doi.org/10.5897/JHF2017.0500.

[45] Zhao, W. G., Chung, J. W., Lee, G. A., Ma, K. H., Kim, H. H., Kim, K. T., Chung, I. M., Lee, J. K., Kim, N. S., Kim, S. M., Park, Y. J. (2011): Molecular genetic diversity and population structure of a selected core set in garlic and its relative using novel SSR markers. - Plant Breeding 130: 46-54. https://doi.org/10.1111/j.1439-0523.2010.01805.x. 